\title{
Implementation of Responsibility Accounting in Electric Power Enterprises
}

\author{
Yechu Han \\ North China Electric Power University, Beijing, China
}

\begin{abstract}
With the continuous development of the economy, the enterprise requires its accounting to complete the transformation from the accounting to the management. As the branch of the management accounting, the responsibility accounting is bound to promote the progress of the enterprise reform work. According to the characteristics of the power enterprise, the accounting system should be in conformity with the accounting system. Although the responsibility accounting plays a significant role in improving the economic efficiency of the enterprise, it is still not mature because the application is still not mature. The problems in the process need to be further analyzed and the solutions are put forward.
\end{abstract}

Keywords-electric power enterprise; responsibility accounting; present situation; question; the way to deal with a situation

\section{INTRODUCTION}

Electric power enterprise is an industrial enterprise engaged in electric power production and management. It is mainly composed of power generation, substation, transmission, distribution and other subsystems. The management system and mode of electric power enterprises also organize, plan, coordinate and control the production and management activities of enterprises which meet the needs of the society according to the objective economic laws and the characteristics of enterprises. With the gradual establishment of the socialist market economy system, the shortcomings of the original management system, which is characterized by administrative management, monopoly management and unified leadership, are constantly exposed. This must be strengthened by reforming the internal management system of the power enterprises.And the vitality of the basic industries will promote the healthy and sustainable development of the national economy.

\section{ThE NeCESSITY OF IMPLEMENTING RESPONSIBILITY ACCOUNTING IN ELECTRIC POWER ENTERPRISES}

The establishment of operation rules of electricity market, the establishment of government supervision agencies, the implementation of new electricity pricing mechanism, and the formation of new mechanisms for encouraging the development of clean power supply are all major breakthroughs in the reform of the power industry. Although electric power enterprises have achieved success in these fields, its reform in financial management and control needs to be improved and innovated, to reduce costs, to scientifically evaluate the performance of various economic units and to improve the economic benefits of enterprises has become the key goal. The transformation and upgrading of enterprises require enterprises to change from extensive management to lean management, and the financial aspect is embodied in accounting to management accounting. Responsibility Accounting is for the purpose of effective control of enterprises The internal accounting system of enterprises which can reflect and evaluate the actual operating performance of each responsibility center in time and correctly can be established by making a reasonable determination of the economic benefits related to the responsibilities of each responsibility center. As an important part of management accounting, responsibility accounting plays an important role in the modern enterprise system, which not only strengthens the internal management of enterprises, but also improves the economic benefits of enterprises. Therefore, it is imperative to carry out responsibility accounting in electric power enterprises.

\section{Application of Responsibility ACCOUNTING IN ELECTRIC POWER ENTERPRISES}

The two prerequisites of responsibility accounting in electric power enterprises are responsibility center and internal accounting system:

Responsibility center: electric power enterprises should be based on their own characteristics and the unique practical needs of internal management. The departments in the enterprise are divided into multiple responsibility centers, and at the same time, the corresponding authority and obligations should be stipulated. Not only the organization of electric power enterprises should be referred to, but also the scope of economic responsibility and management authority of each internal accounting unit should be stipulated, and the responsibility center should be established scientifically and reasonably with its main responsible person as the responsible bearer.

Internal Accounting system: our country's responsibility Accounting system, in our country Enterprise Internal Economic Accounting System on the basis of its internal structure, to perfect the internal accounting system among the responsibility centers, and to determine various types of internal settlement prices, which can reasonably reflect the economic responsibilities that each responsibility center should bear. In order to provide an objective basis for the assessment of each responsibility center.

On this basis, the establishment of a responsibility accounting system in line with the power enterprise, the specific procedures and steps are as follows:

First of all, the enterprise should establish the responsibility center to determine the scope of responsibility. Responsibility center is the basic problem of the development and reform of 
responsibility accounting. The goal of establishing responsibility center system is to carry out economic responsibility. The correct division of responsibility center is an important symbol of the establishment of responsibility accounting system in enterprise management. Normally, the responsibility center is divided into three parts: cost as the responsibility center, profit as the responsibility center and investment as the responsibility center. The cost center is mainly responsible for the controllable cost. Profit centers need to be responsible not only for costs but also for profits, while investment-centric ones need to be responsible for all three.

Power enterprises mainly include construction, logistics services, electrical manufacturing and other businesses, with emphasis on construction business. According to the requirements of establishing responsibility center, electric power enterprises can establish profit center, revenue control center, cost control center and safety quality control center for the controllable cost of each functional department or responsible person. In general, each subsidiary of an electric power enterprise has the right to sell products, the right to purchase materials and the right to make decisions, so it can be determined as a center of natural profits. Each subsidiary group or workshop can be defined as a profit center according to its management power. Operations within subsidiaries the development department can be identified as the income control center, which should be responsible for the company's production, construction tasks, income contracts, claims, and production and management. The human capital, material, production and construction of the subsidiary companies are determined as the center of cost control. According to the characteristics of the power enterprise industry, the production and construction technology department is sure. It is designated as the technical quality cost control center; the human capital department is recognized as the cost control center of the artificial cost; the material supply department is recognized as the material cost cost control center; the financial department is recognized as the controlled cost control center. Each confirmed cost control center should overspend the actual cost of the power enterprise or The part of the loss is directly responsible. The Safety quality Control Center shall be responsible for the safety and quality loss of the responsible unit.

Then the enterprise should prepare the responsibility budget according to its own situation and establish the goal of responsibility center. The establishment of units based on individual responsibility centres requires the preparation of corresponding responsibility budgets, as well as the need for responsibility centres to identify responsibility objectives for a given management cycle, and carries on the management to the target cost and carries on the related target cost accounting. First of all, it is necessary to establish an incentive system for each responsibility center in order to fully mobilize the enthusiasm of each responsibility center by linking the determination of the target responsibility with the remuneration of the responsibility unit. At the same time, responsibility centres also need to ensure that responsibility goals are fully tested in the process. Considering the specific situation of each responsibility center and combining with the management requirements of the enterprise, we should give full play to the enthusiasm of the staff work as the basis, and set out the responsibility goal which is conducive to the sustained and healthy development of the enterprise and the full play of the enthusiasm of the staff.

The key work of the electric power enterprise is to compile the total budget of the group, on the basis of which, the budget of the group is decomposed according to a certain method, and it is conscientiously implemented to the responsibility center of each unit and department. The characteristic of electric power enterprise is that the construction business accounts for a large proportion, the enterprise budget can be based on the base period data, considering the expected changes of various factors to prepare the business budget. After the completion of the business budget, the electric power enterprise should take each responsibility center as the object to decompose the relevant contents of the business budget, including income, cost, profit and capital occupation. When specifically decomposed, electricity The business budget can be divided into several sub-indexes, and the total number of sub-indexes is equal to the budget index number. The subbranch team or project group can be decomposed by the index deformation decomposition method until the individual.

In order to ensure the successful completion of the responsibility budget of electric power enterprises, it is also necessary to control the execution process of the responsibility budget. These include responsible fund budget, cost budget and profit budget control.

The final procedure for the compilation of financial reports, the completion of the corresponding assessment work. For responsibility accounting, financial reporting and assessment of responsibility goals are key tasks. After the establishment of the responsibility budget and the responsibility target, the completion of the responsibility center needs to be evaluated in a certain accounting period, which requires the preparation of the performance statement of the responsibility center based on the daily records. And the completed responsibility indicators and the original plan of the responsibility indicators comparative analysis. The results of each responsibility center should be evaluated through the relevant comparative analysis. In the process, the problems existing in each responsibility center should be analyzed and the corresponding solutions should be taken. And methods to confirm and approve the final results of the responsibility center. At the same time, at the end of each accounting period, it is also necessary to conduct business results accounting, to evaluate the income situation in this process, and to provide the basis for the establishment of liability indicators in the next accounting period.

\section{Problems And SOlutions IN The Application of RESPONSIBILITY ACCOUNTING}

\section{A. Problems in the Process of Application}

\section{1) Lack of high-quality accountants}

At present, the electric power enterprises that have adopted the responsibility accounting system use the "monorail system" responsibility accounting system. A set of accounting books is set up in "monorail system" for unified accounting, and the difference between the two can be adjusted by certain methods. Such a system increases the difficulty and workload of 
accountants. At present, although some enterprises have carried out computerization, but only in the primary stage of auxiliary accounting, few enterprises use computer to predict, control, analyze and other management activities. Therefore, the superiority of responsibility accounting is difficult to play, and the application of responsibility accounting in enterprises is restricted.

\section{2) Unreasonable method of application}

In the application of the responsibility accounting system, the enterprise has not combined the actual situation of the enterprise, blindly referring to the application method of the western enterprise responsibility accounting system, which makes the responsibility accounting unable to play its due role in the modern enterprise system.

\section{3) Flawed accountability targeting mechanism}

Different responsibility centers are different in nature and cannot be measured by agreed performance comparisons. If we blindly adopt the unified responsibility target determination mechanism, it will inevitably have advantages to some responsible units and unfair to some responsibility units, which will adversely affect the work enthusiasm of employees.

\section{4) Imperfect Evaluation system of responsibility} Accounting

Due to the problem of overstaffing in electric power enterprises, resources are idle, which to a great extent increases the unit cost of the enterprises, reduces the production efficiency of the enterprises, and restrains the full play of the role of responsibility accounting. Moreover, the one-sided cost index evaluation will be counterproductive to the incentive system of the enterprise, which is not conducive to the realization of the goal of responsibility accounting, and the existing evaluation system is difficult to meet the needs of modern enterprise production management.

\section{B. Solutions}

\section{1) The cultivation of High quality Accounting talents}

Strengthen the in-service training for the internal personnel of the electric power enterprise, bring the training of responsibility accounting and the computerization of accounting into the accounting personnel education system, and train the compound talents who meet the requirements of the modern enterprises in mastering the application of responsibility accounting and accounting computerization.

\section{2) Establishment of Scientific Application method}

In the process of popularizing the responsibility accounting system, we should not blindly pursue the speed and ignore the quality, and do a good job in consolidating the development work. Because the factory system is suitable and does not apply the western pattern rigidly, the enterprise should proceed from the reality and perfect its own responsibility accounting system.

\section{3) Perfection of responsibility Accounting system}

The electric power enterprise should formulate the unified operation and management target of the electric power enterprise, and then decompose the total goal into the target of each responsibility center. Then each responsibility unit specific responsibility determination according to the responsibility to give corresponding power. Finally, the establishment of a unified accountability system, and pay linked. According to different responsible units and evaluation objects, different performance appraisal methods should be given, and the corresponding accounting and incentive methods should be adopted to arouse the enthusiasm of each responsible unit and to improve the overall economic benefit of the enterprise.

To sum up, the new era requires higher management of electric power enterprises, and the application of responsibility accounting can not only strengthen internal control, but also improve the production efficiency of enterprises. The correct application of responsibility accounting provides good help for the development of electric power enterprises. In the course of its implementation, the electric power enterprise should set out the responsibility accounting system according to its own actual situation, and should absorb and learn from the successful experience. Electric power enterprises follow the pace of the times to continue to develop will also create a new vitality of the industry.

\section{REFERENCES}

[1] Shu-fang Niu. The Application of responsibility Accounting in Chinese Enterprises [J]. Educational Accounting Research 21 (01): 55-58.

[2] Hui-qi Zhao. A study on the implementation of responsibility Accounting in Enterprises Taking Electric Power Enterprises as an example [J]. Chinese business theory: 2017 (13): 76-77.

[3] Xue-ling Cai,Qi Zhang,Liang Yang. The role of responsibility Accounting in Modern Enterprise system [J]. Modern economy: 2015 (08): 233,235.

[4] Xiao-ya Huo,Shuang Liang. Application of responsibility Accounting in Enterprise Management [J]. Electronic production 2014 ( 15): 271.

[5] Rong-gui Ma. Application of responsibility Accounting in Enterprises [J]. Journal of Jiaozuo Institute of Technology (Social Sciences Edition) 2002 (03): 31-32. 